\title{
Comment
}

\section{THE EPIDERMIS AND CYCLIC AMP}

A hormone induces a rapid and profound change in the metabolic balance of its target organ. Early studies emphasized the extraordinarily low concentrations in which many hormones are effective. The fact that catecholamines and polypeptides are frequently unable to penetrate the surface of cells made this seem all the more remarkable. The mechanism of their action, which for many years remained a central problem of molecular biology, was finally resolved by the discovery of adenosine $3^{\prime}, 5^{\prime}$ monophosphate (cyclic AMP) in 1958 by Sutherland \& Rall. It subsequently became apparent that cyclic AMP was the intracellular second messenger for those hormones that by themselves could not penetrate inside the cell.

An overall but abbreviated sequence of events is shown in Fig. I. When activated by cyclic AMP, a cyclic AMP dependent protein kinase may phosphorylate many different proteins, both enzymatic and structural. In some cases this results in their activation, whereas in others the protein is converted to a biologically inactive form. Thus, co-ordinate control over several different pathways is accomplished. In addition, the amplification obtained by linking enzymic reactions in cascade is considerable; one may visualize how a cell could respond to a very few molecules of the external hormone (the 'first messenger'). The most comprehensive review of the general literature is the monograph of Robison, Butcher \& Sutherland (I97I), which includes a bibliography of over 1500 references to cyclic AMP. It is notable but not surprising that this literature deals with almost every mammalian tissue except epidermis.

Does the 'second messenger' system in fact operate in mammalian epidermis? Adenylate cyclase activity was first described in homogenates of whole guinea-pig skin (Mier \& Urselmann, 1970a), but no hormonal stimulation could be demonstrated. Using a particulate fraction isolated from epidermis, Duell et al. (1971) and Marks \& Rebien (1972a) were able to show some degree of stimulation by catecholamines, although this was still very small compared with other tissues. Intact epidermal cells, on the other hand, respond vigorously; for example, Powell, Duell \& Voorhees (197I) found a threefold increase in the cyclic AMP content of rat epidermis following exposure to isoproterenol, and Brønstad, Elgjo and Øye (197I) reported increases of more than ten-fold in the synthesis of cyclic AMP by whole hamster skin in response to adrenalin. Thus, it is now clear that this part, at least, of the system is functional.

The other two enzymes shown in Fig. I have now also been described in mammalian skin. The enzyme responsible for lowering cellular levels of cyclic AMP after hormonal stimulation has ceased, cyclic AMP phosphodiesterase, was examined in whole mouse skin (Mier \& Urselmann, 1972) and found to have a $\mathrm{K}_{\mathrm{m}}$ of $9 \times 10^{-5} \mathrm{M}$ and was inhibited by methyl xanthines. The high $\mathrm{K}_{\mathrm{m}}$ cyclic $\mathrm{AMP}$ phosphodiesterase has been measured in both involved and uninvolved psoriasis epithelium and appears to be unaltered (Voorhees et al., 1973a). The low $\mathrm{K}_{\mathrm{m}}$ activity might be increased in the lesion in comparison to the uninvolved areas (Voorhees et al., 1974a). Cyclic AMP dependent protein kinase has been investigated in whole human skin (Kumar, Tao \& Solomon, 197I), in whole mouse skin (Mier \& van den Hurk, 1972) and in human epidermis (Voorhees et al., 1974b); the cutaneous enzyme seems very similar to those from other tissues. Although certain of these results pertain to whole skin, the preponderance of epidermal cells in such preparations and the demonstration of all the components of the cyclic AMP system in human epidermis (Voorhees et al., 1974a) makes it 


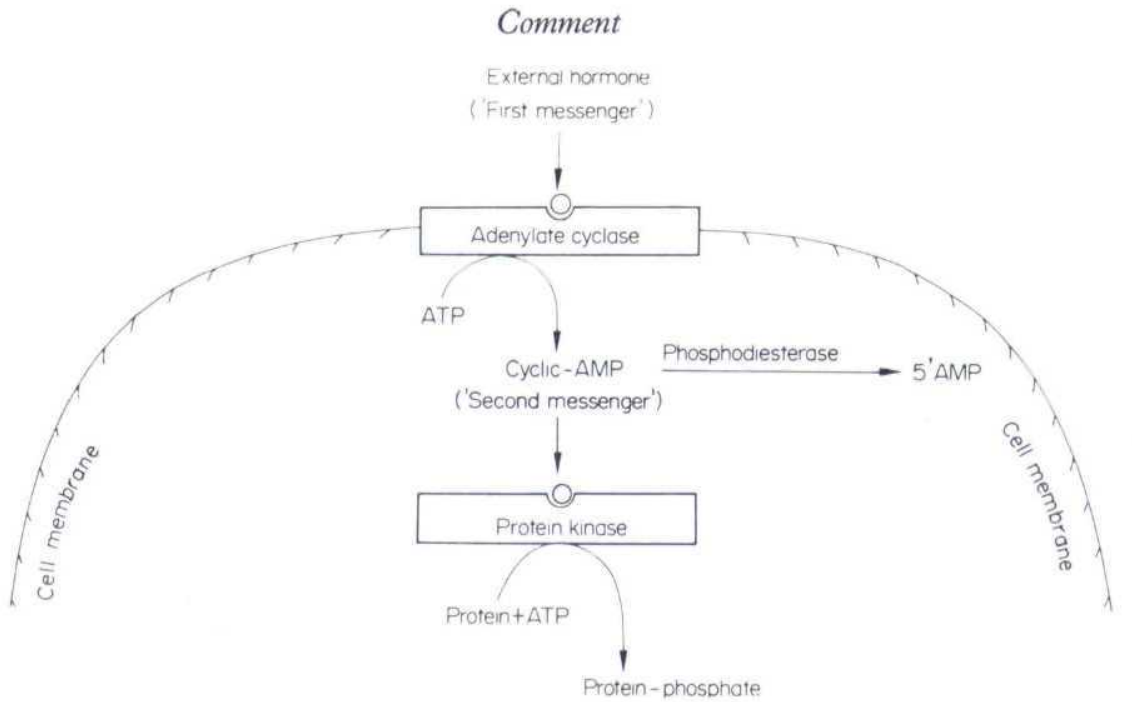

FIGURE I. The 'cyclic AMP cascade'. Both enzymatic and structural proteins may be phosphorylated by the cyclic AMP-dependent protein kinase.

reasonable to conclude that epidermis is indeed equipped with a complete 'second messenger' system.

But what 'message' does this system carry ? The activity of many internal tissues must be linked to the minute-to-minute needs of the body as a whole; since epidermis (as far as we know) does not secrete metabolites vital to other organs, it is more difficult to understand the need for such continuous hormonal supervision. What epidermis does provide, however, is a highly specialized barrier between the 'inside' and the 'outside'. An important parameter, therefore, is its thickness; one must presume the existence of a homeostatic device to balance the proliferative rate of the basal cells with the rate of desquamation from the surface. This homeostasis has been studied extensively by Bullough, who introduced the now familiar concept of the epidermal chalone (Bullough, I962). In the course of this work it was established that catecholamines are powerful inhibitors of epidermal cell division.

Voorhees \& Duell (I97I) proposed that cyclic AMP mediates this catecholamine induced inhibition of proliferation. This hypothesis not only assigns a physiological function to the 'second messenger' in epidermis, but also explains (via the activation of glycogen synthetase and the inactivation of glycogen phosphorylase) (Fig. 2) why an accumulation of glycogen generally accompanies enhanced epidermal proliferation. In essence, the Voorhees-Duell hypothesis suggests that cyclic AMP is a major regulator (not necessarily the only one) of epidermal thickness and function. However, which hormone, if any, modulates intraepidermal cyclic AMP levels is unknown. The experimental support for this hypothesis is now considerable, and includes the following observations:

(I) In vitro studies have shown that cyclic AMP directly inhibits epidermal cell division in a dosedependent manner (Marks \& Rebien, I972b; Voorhees, Duell \& Kelsey, 1972). In fact, the four criteria of Robison et al. (197I) of a cyclic AMP mediated event (inhibition of epidermal cell division) have been met (Voorhees et al., 1973a).

(2) In rapidly dividing epithelium, such as the psoriatic plaque, the level of cyclic AMP in vivo is decreased (Voorhees et al., 1972).

(3) The degree of activation of phosphorylase (Mier \& van den Hurk, 1974) has been reported as lower than normal in the psoriatic plaque.

(4) Wright et al. (1973) claim to have found a reduced rate of cyclic AMP synthesis in the psoriatic 


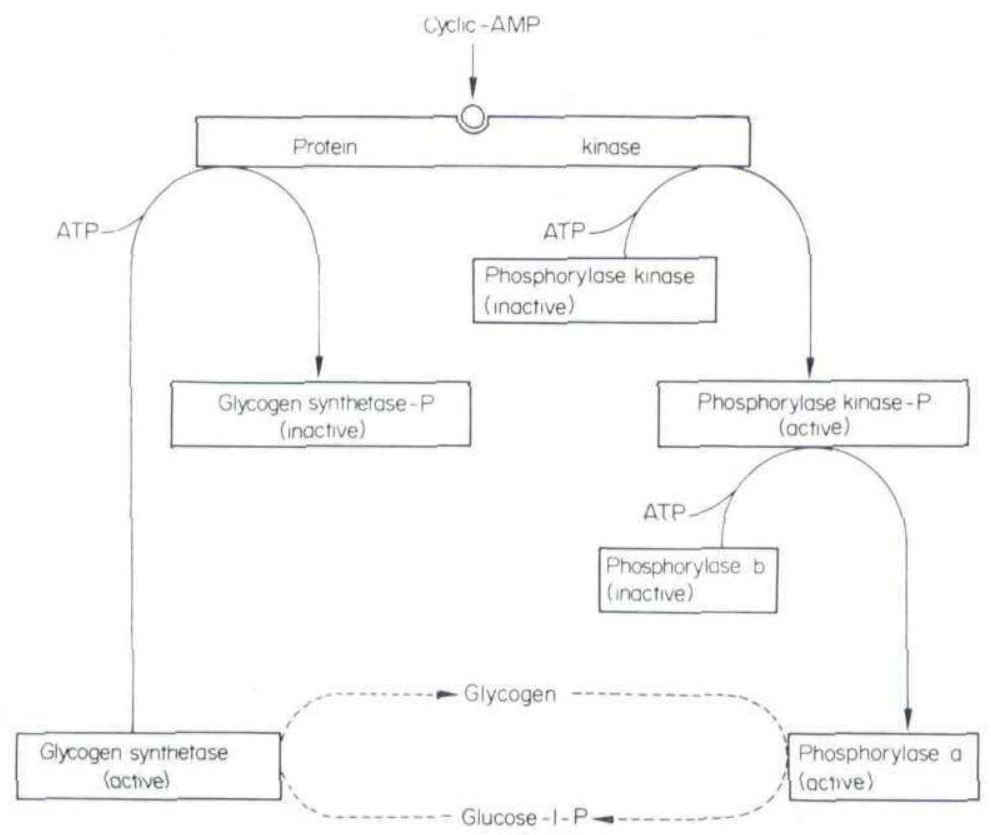

FIGURE 2. Control of glycogen metabolism via the activation of protein kinase. Most of the components of this pathway have now been demonstrated in epidermis.

plaque. This may be the case but requires further work and confirmation, as discussed by Voorhees et al. (1973a).

Can the pathogenesis of any of the familiar dermatoses be related to a defective 'second messenger' system? So far two hypothesis have been offered. The earlier of these was the attempt by Szentivanyi (1968) to describe the clinical manifestations of atopy in such terms. Despite considerable circumstantial evidence in support of this idea, direct measurements of the three enzymes concerned (Fig. I) in four to six patients have failed to reveal any abnormality (Mier \& Urselmann, I970b; Holla et al., 1972; Mier et al., 1972). Although the enzyme activities are apparently normal in vitro, any final conclusions must await study of factors which may interfere with the function of these enzymes in vivo and the study of the adenylate cyclase receptors at the cell surface.

The more recent, and more promising, line of thought relates to psoriasis. The original suggestion of a defective cyclic AMP cascade in this disease was made by Voorhees \& Duell (I97I). As we have already pointed out, subsequent reports seem to support this notion that both the high proliferative rate and the accumulation of glycogen in the psoriatic lesion are due to a co-ordinate misregulation occasioned by reduced cyclic AMP levels. This provides an important new link in the pathogenic chain, but in no sense tells us the 'primary cause' of the disease. It would, of course, be tempting to equate the familial predisposition to psoriasis with an inherited abnormality of adenylate cyclase, cyclic AMP phosphodiesterase or the adenylate cyclase receptor. Current evidence, however, suggests that the disturbed cyclic AMP balance may be secondary to some other process-an inhibition of adenylate cyclase function or a stimulation of cyclic AMP phosphodiesterase in vivo without a major genetic defect in either enzyme (Voorhees et al., 1973a).

In conclusion, it is perhaps pertinent to comment that the ro-year lag which has been customary before new 'scientific' thought is assimilated into dermatology seems at last to be diminishing. Skin is finally becoming an acceptable tissue for molecular biologists to investigate, and clinicians are becom- 
ing more aware that an understanding of many diseases in sufficient depth to lead to better therapy is possible only in molecular terms. If this trend continues, the following decade will be an exciting one for us all. Perhaps the most intriguing line of investigation in this area at the present time is the interrelation between cyclic AMP and cyclic GMP in epidermal physiology (Voorhees et al., 1973a, I973b; Voorhees et al., 1974a, I974b). The role of cyclic GMP in epidermal homeostasis will be the subject of a future commentary.

University of Michigan Medical School,

J.J.VOORHEES

Ann Arbor, Michigan,

U.S.A.

Department of Dermatology,

P.D.MIER

University of Nijmegen,

The Netherlands

\section{REFERENCES}

BRønstad, G.O., ElGJo, K. \& ØYE, I. (I97I) Adrenaline increases cyclic 3'5'-AMP formation in hamster epidermis. Nature New Biology, 233, 78.

Bullough, W.S. (1962) The control of mitotic activity in adult mammalian tissues. Biological Reviews, 37, 307.

Duell, E.A., Voorhees, J.J., Kelsey, W.H. \& HAYeS, E. (I97I) Isoproterenol-sensitive adenyl cyclase in a particulate fraction of epidermis. Archives of Dermatology, 104, 601.

Holla, S.W.J., Hollman, E.P.M.J., Mier, P.D., van der StaAk, W.J.B.M., Urselmann, E. \& Warndorff, J.A. (1972) Adenosine $3^{\prime}: 5^{\prime}$-cyclic monophosphate phosphodiesterase in skin. II. Levels in atopic dermatitis. British fournal of Dermatology, 86, 147.

Kumar, R., TAO, M., \& Solomon, L.M. (I97I) Cyclic 3',5'-adenosine monophosphate-stimulated protein kinase from human skin. Fournal of Investigative Dermatology, 57, 312.

MARKs, F. \& Rebien, W. (I972a) The second messenger system of mouse epidermis. I. Properties and $\beta$-adrenergic activation of adenylate cyclase in vitro. Biochimica et biophysica acta, 284, 556 .

MARKs, F. \& Rebien, W. (r972b) Cyclic 3',5'-AMP and theophylline inhibit epidermal mitosis in $\mathrm{G}_{2}$-phase. Naturwissenschaften, 59, 4I.

MieR, P.D. \& Urselmann, E. (1970a) The adenyl cyclase of skin. I. Measurements and properties. British fournal of Dermatology, 83, 359.

Mier, P.D. \& Urselmann, E. ( $1970 \mathrm{~b}$ ) The adenyl cyclase of skin. II. Adenyl cyclase levels in atopic dermatitis. British fournal of Dermatology, 83, 364 .

Mier, P.D. \& Urselmann, E. (I972) Adenosine $3^{\prime}: 5^{\prime}$-cyclic monophosphate phosphodiesterase in skin. I. Measurement and properties. British fournal of Dermatology, 86, I4I.

MIER, P.D. \& VAN DEN HURK, J. (1972) Cyclic 3',5' adenosine monophosphate-dependent protein kinase of skin. I. Measurement and properties. British fournal of Dermatology, 87, 57x.

Mier, P.D., van Den Hurk, J., Holla, S.W.J., Hollman, E.P.M.J., Porters, J.E. \& Weemers, M.B.M. (I972) Cyclic 3',5' adenosine monophosphate-dependent protein kinase of skin. II. Levels in atopic dermatitis and psoriasis. British fournal of Dermatology, 87, 577.

MIER, P.D. \& VAN DEN HURK, J. (1974) In preparation.

Powell, J.A., Duell, E.A. \& VoorheES, J.J. (I97I) Beta adrenergic stimulation of endogeneous epidermal cyclic AMP formation. Archives of Dermatology, 104, 359.

Robison, G.A., Butcher, R.W. \& Sutherland, E.W. (I97I) In: Cyclic AMP. Academic Press, New York.

SUTHERLAND, E.W. \& RALL, T.W. (1958) Fractionation and characterization of a cyclic adenine ribonucleotide formed by tissue particles. Fournal of Biological Chemistry, 232, 1077.

Szentivanyi, A. (1968) The beta adrenergic theory of the atopic abnormality in bronchial asthma. Fournal of Allergy, 42, 203.

VoorheEs, J.J. \& DUell, E.A. (197I) Psoriasis as a possible defect of the adenyl cyclase-cyclic AMP cascade. Archives of Dermatology, 104, 352.

VoorheEs, J.J., Duell, E.A. \& KeLSEY, W.H. (1972) Dibutyryl cyclic AMP inhibition of epidermal cell division. Archives of Dermatology, 105, 384 . 
Voorhees, J.J., Duell, E.A., Bass, L.J., Powell, J.A. \& Harrell, E.R. (1972) Decreased cyclic AMP in the epidermis of lesions of psoriasis. Archives of Dermatology, 105, 695.

Voorhees, J., Kelsex, W., Stawiski, M., Smith, E., DUell, E., Haddox, M. \& Goldberg, N. (1973a) Increased cyclic GMP and decreased cyclic AMP levels in the rapidly proliferating epithelium of psoriasis. In: The Role of Cyclic Nucleotides in Carcinogenesis (Ed. by J. Schultz and H.G. Gratzner), vol. 6, p. 325. Academic Press, New York.

Voorhees, J.J., Stawiski, M., Duell, E.A., Haddox, M.K. \& Goldberg, N.D. (1973b) Increased cyclic GMP and decreased cyclic AMP levels in the hyperplastic, abnormally differentiated epidermis of psoriasis. Life Sciences, 13, 639.

Voorhees, J.J., Colburn, N.H., Stawiski, M., Duell, E.A., Haddox, M. \& Goldberg, N.D. (1974a) Imbalanced cyclic AMP and cyclic GMP levels in the rapidly dividing, incompletely differentiated epidermis of psoriasis. In: The Cold Spring Harbor Laboratory Symposium on Regulation of Proliferation in Animal Cells (Ed. by B. Clarkson and R. Baserga), in press. Cold Spring Harbor Laboratory, New York.

Voorhees, J.J., Duell, E.A., Stawiski, M. \& HARRell, E.R. (1974b) Cyclic nucleotide metabolism in normal and proliferating epidermis. In: Advances in Cyclic Nucleotide Research (Ed. by P. Greengard and G.A. Robison), vol. 4, in press. Raven Press, New York.

Wright, R.K., MANDY, S.H., Halprin, K.M. \& Hsia, S.L. (1973) Defects and deficiency of adenyl cyclase in psoriatic skin. Archives of Dermatology, 107, 47 . 
This document is a scanned copy of a printed document. No warranty is given about the accuracy of the copy. Users should refer to the original published version of the material. 